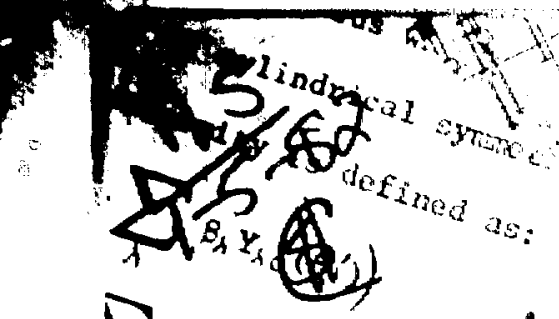

7

$\left.\sim s_{\lambda} y_{\lambda}=(\theta)\right)$.

2. MASTER

$$
\text { onarace. }
$$
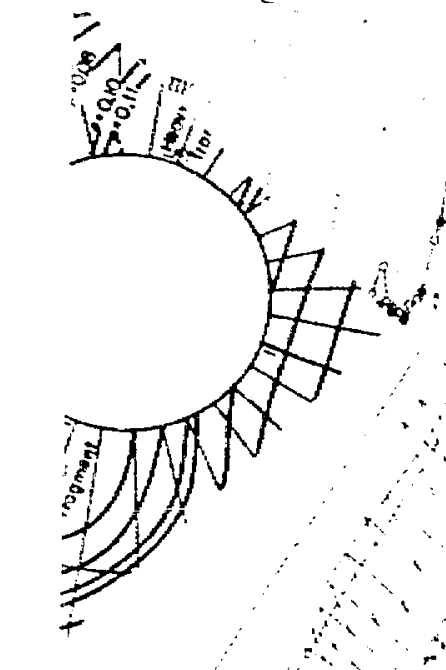
MASTER

THE URANIUM HALF-LIVES: A CRITICAL REVIEW

\author{
Horman E. Holden
}

January 1981

INFORINATION ANALYSIS CENTER REPORT
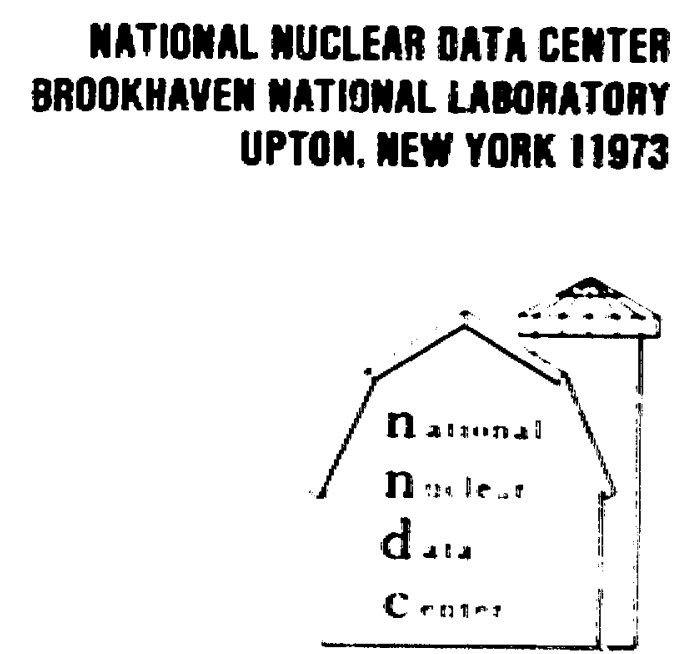

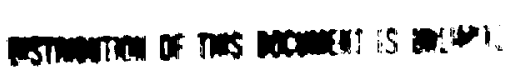




\title{
THE URANIUM HALF-LIVES: A CRITICAL REVIEW
}

\author{
Norman E. Holden
}

January 1981

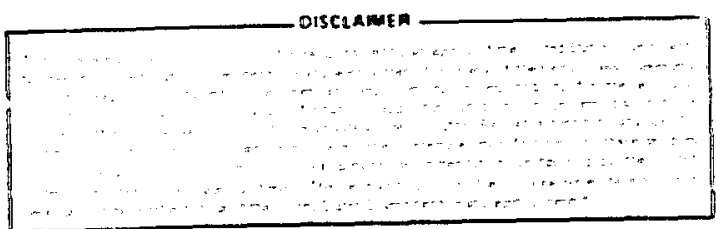

IMFORMATION AMALYSIS CENTER REPORT

MATIONAL MUCLEAR DATA CENTER BROOKHAVEN MATIONAL LABORATORY

ASSOCIATED UNIVERSITIES. IME. 


\section{ABSTRACT}

This report evaluates the experimental data and recormends values for the spontaneous fission half-1ife of $238_{\mathrm{U}}$, and the total half-1ives for ${ }^{232} \mathrm{U},{ }^{233} \mathrm{U},{ }^{234} \mathrm{U},{ }^{235} \mathrm{U},{ }^{236} \mathrm{U}$, and ${ }^{238} \mathrm{U}$. The repurt also discusses the variation of the isotopic abundance of ${ }^{234} \mathrm{U}$ in nature and the error involved in the assumption of secular equilibrium between $234_{\mathrm{U}}$ and $238_{\mathrm{U}}$ in the determination of the specific activity of natural uraniom samples.

The recommended half-life values and $95 \%$ confidence 1 imits are: $238_{\mathbb{U}}$ spontaneous fission: $8.09 \pm 0.26 \times 10^{15}$ years; $232 \mathrm{v}$ total: $69.8 \pm 1.0$ years; ${ }^{233} \mathrm{U}$ total: $1.592 \pm 0.002 \times 10^{5}$ years; ${ }^{234} \mathrm{U}$ total: $2.454 \pm 0.006 \times 10^{5}$ years; $235_{\text {total }}: 7.037 \pm 0.011 \times 10^{8}$ years; ${ }^{236} \mathrm{u}$ torai: $2.342 \pm 0.003 \times 10^{7}$ years 238 total: $4.468 \pm 0.005 \times 10^{9}$ years. 


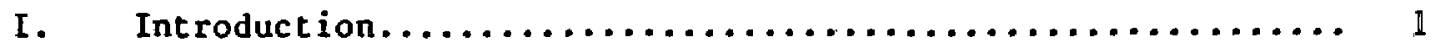

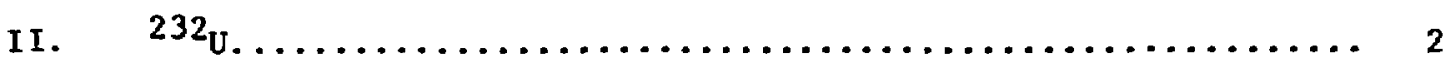

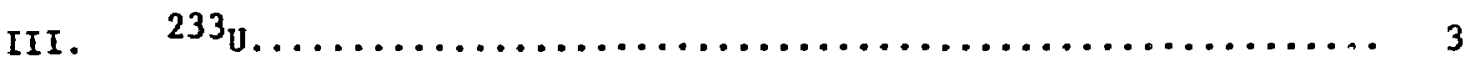

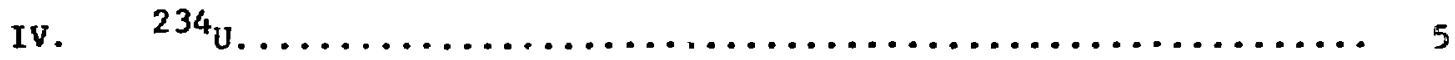

v. $\quad 235_{\mathrm{U}} \ldots \ldots \ldots \ldots \ldots \ldots \ldots \ldots \ldots \ldots \ldots \ldots \ldots \ldots \ldots \ldots \ldots$

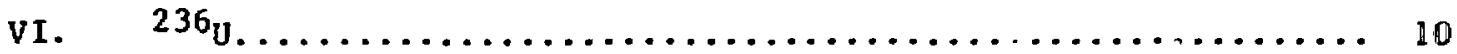

VII. $\quad{ }^{238_{U-T o t a l}}$ Half-life........................ 12

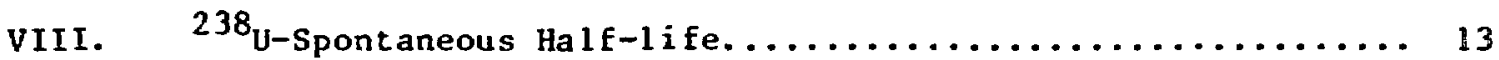

IX. $\quad$ Sumnary............................... 15

Appendix I Specific Activity of Natural Uranium....... 17

Appendix II Natural Variation of the Uranium

Isotopic Composition. ............... 19

Appendix III Parameters of the Evaluation............ 23

References................................ 23

\section{List of Tables}

Table

Page

${ }^{232} \mathrm{U}$ Ha $1 \mathrm{f}-1$ ife.

$233_{\mathrm{U}}$ Half-1ife.

$3 \quad 234_{\mathrm{U}} \mathrm{Ha} 1 \mathrm{f}-1 \mathrm{ife} \ldots \ldots \ldots \ldots \ldots \ldots \ldots \ldots \ldots \ldots \ldots \ldots \ldots \ldots \ldots$

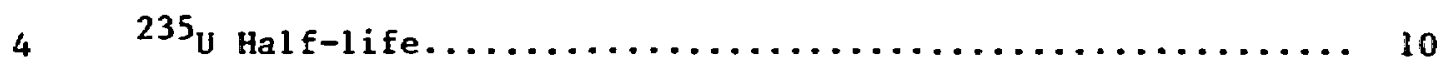

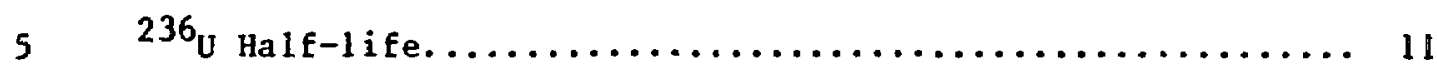

$6 \quad 238 \mathrm{U}$ Spontaneous Fission Decay Constant, $\lambda_{\mathrm{f}}{ }^{238}$ and Standard Deviation....................... I4 


\section{Table of Contents. continued}

Table

Page

7 Recommended Half-life and Specific Activity Values....... \&5

8 Specific Activity of Natural Uranium............... 18

9 Uranium Isotopic Composition (U. S. samples)........... 20

10 Uranium Isotopic Composition (Non U.S.A. samples)......... 21 


\section{INTRODUCTION}

The half-lives (partial or total) of the uranium isotopes are of interest for many applications. The total half-lives are of interest for standards purposes and the spontaneous fission half-ilfe of ${ }^{238} \mathrm{U}$ is used in the assay of low-enrichment uranium oxide in bulk containers for safeguards purposes via spontaneous fission neutrons.

The impetus for this study is a re-evaluation of the thermal neutron cross sections and related parameters of the uranium and plutonium fissile nuclides. The haif-lives are required to determine the amounts of materials from the measured activities of the nuclides.

A number of measurements of the ${ }^{234} \mathrm{U}$ and the ${ }^{238} \mathrm{U}$ half-lives have been based on the assumption of secular equilibrium; i.e., the much shorter-lived ${ }^{234} \mathrm{U}$ daughter has the same specific activity in a sample as it's longer-lived ${ }^{238} \mathrm{U}$ parent (see Appendix I). However, knowledge of the isotopic abundance variation of ${ }^{234} \mathrm{U}$ in nature ${ }^{1,2}$ (see Appendix II) and the $234 \mathrm{U} / /^{238_{\mathrm{V}}}$ disequilibrium st.udies in groundwater since $1955^{3}$ imply that caution should be exercised in utilizing the assumption of secular equilibrium in half-1ife measurements. Unless a separate determination of the isotopic composition of a sanple is made, measurements on natural uranium may not provide an accurate value for the half-1ife of ${ }^{234} \mathrm{U}$ or ${ }^{238} \mathrm{U}$.

In the following review, the various uranium nuclides are discussed in turn and the significant measurements are described and assessed. An iterative procedure is used whereby the evaluation and recommended values f.r other isotopes are utilized to update a given half-life, which in turn is used to update the measurements for the other isotopes.

It should be noted that in the following tables, the uncertainty at the 95\% confidence level has been 1 isted. It was determined from the author's quoted uncertainty.

The various constants and masses assumed for conversion purposes in this study are discussed in Appendix III. In general, the specific activity has been the measured quantity in the experiments discussed and the values from Appendix III are used to update the half-life value quoted in each experiment. 


$$
\text { II. }{ }^{232} \mathrm{U}
$$

Sellers ${ }^{4}$ used isotope dilution mass spectrometry and alpha proportional counting to determine the activity of a ${ }^{238} \mathrm{U}$ sample containing $0.14 \%{ }^{232} \mathrm{U}$. The specific activity of $232 \mathrm{U}$ was fount to be $4.65 \times 10^{10}$ disintegrations per minute per milligram (dpm/mg) (corresponding to a half-1ife $73.56 \pm 1.48$ years at the $68 \%$ confidence level or 1 standard deviation). The $232 \mathbb{U}$ daughter activity was corrected for.

Chilton 5 used both alpha proportional counting and calorimetry to determine the specific activity of a sample of $99.2 \%$ enriched $232 \mathrm{y}$. There was a 1.1\% difference between Chilton's two results. The weighted mean was $4.772 \pm 0.057 \times 10^{10} \mathrm{dpm} / \mathrm{mg}$ (corresponding to a half-1ife $71.67 \pm 0.86$ years at the $95 \%$ confidence limit or 2 standard deviations). $232 \mathrm{U}$ daughter activity was corrected for.

Aggarwal ${ }^{6}$ determine the specific activity of a ${ }^{238} \mathrm{U}$ sample containing $16.5 \% 23 \hat{L}_{\mathrm{U}}$ using liquid scintillation counting and alpha proportional counting, masses were determined by isotope dilution mass spectrometry. ${ }^{232} \mathrm{U} /{ }^{233} \mathrm{U}$ relative activity was also used to determine the specific activity of ${ }^{232} \mathrm{U}$. The specific activity from liquid scintillation counting and alfha counting was $4.96 \pm 0.03 \times 10^{10} \mathrm{dpw} / \mathrm{mg}$ (corresponding to a half-life of $69.0 \pm 0.4$ years). The half-life from the $232 \mathrm{v} / i^{233} \mathrm{U}$ activity ratio was $68.8 \pm 0.4$ years. The standard error of the mean and the standard deviations reported have been converted to a $95 \%$ confidence limit and the half-1ife from Aggarwal is $68.90 \pm 0.56$ years.

The weighted average for the ${ }^{232} \mathrm{U}$ half-1ife from the three measurements described above is $69.78 \pm 0.99$ years. 
Table $1{ }^{232}$ U Half-Life

\begin{tabular}{|c|c|c|c|c|}
\hline Author (year) & Reference & $\begin{array}{l}\text { Total Half-Life } \\
\text { Value (years) }\end{array}$ & Method & Comment \\
\hline Se1lers (1954) & 4 & $73.6 \pm 3.0$ & $\begin{array}{l}\alpha \text { Proportional } \\
\text { counting }\end{array}$ & \\
\hline Chilton (1964) & 5 & $71.7 \pm 0.9$ & $\begin{array}{l}\alpha \text { Proportional } \\
\text { counting and } \\
\text { coulometry }\end{array}$ & $\begin{array}{l}50 \% \\
\text { geomet ry }\end{array}$ \\
\hline Aggarwal (1979) & 6 & $68.90 \pm 0.56$ & $\begin{array}{l}\alpha \text { Proportional } \\
\text { counting, liquid } \\
\text { ecintillation } \\
\text { counting and } \\
232 \mathrm{U} / 233_{\mathrm{U}} \\
\text { relative activity }\end{array}$ & \\
\hline Holden (1980) & & $69.8 \pm 1.0$ & Weighted average & $\begin{array}{l}\text { Recommended } \\
\text { value }\end{array}$ \\
\hline
\end{tabular}

$$
\text { III. }{ }^{233} \mathrm{U}
$$

Up until 1974, there had been two groups of measurements o.a the ${ }^{233} \mathrm{U}$ half-life which differed by $5 \%$. It had not been possible to explain the discrepancy between these groups. Durham ${ }^{7}$ reported a preliminary measurement on alpha proportional counting with small solid angle, which was intermediate between the two previous groups. However this report has never been published and it, along with all earlier measurements, has been discarded. This evaluation is based on the four subsequent measurement described below. The measurements used highly enriched samples of $233_{\mathrm{U}}\left(98.1 \%\right.$ to $\left.99.99 \% 233_{\mathrm{J}}\right)$.

Jaffey 8 measured the specific activity of a $99.5 \%$ enriched sample of ${ }^{23} \mathrm{U}$ using intermediate geometry alpha proportional counting. ${ }^{238} \mathrm{Pu}$ (1ater corrected for), ${ }^{232} \mathrm{U}$ and ${ }^{234} \mathrm{U}$ contributed to the activity. Silicon junction detectors were used for the pulse helght energy analysis. The specific activity reported was $21405 \pm 20 \mathrm{dpm} / \mu \mathrm{gram}{ }^{233} \mathrm{U}$, (corresponding to a half-11fe of $1.5910 \pm 0.0015 \times 10^{5}$ years with the uncertainty for the standard error of the mean). 
Vaninbroukx ${ }^{9}$ determined the specific activity of samples enriched to $99.762 \%$ and $99.9986 \% 233 \mathrm{U}$ by alpha counting in low geometry, in a liquid scintillator and by $4 \pi$ proportional counting. Isotope dilution mass spectrometry was used to determine the $233_{\mathrm{U}}$ content as well as controlled potential coulometry. The resulting half-life is $1.5925 \pm 0.0040 \times 10^{5}$ years, where the error is the $99.7 \%$ confidence 1 imit.

Geidel'man ${ }^{10}$ measured the specific activity of a $98.112 \%$ enriched $233_{\mathrm{U}}$ sample using $4 \pi$ alpha- $X$ coincidence. Potentiometric titration was used to determine the uranium concentration in the sample. The result obtained is $1.5937 \pm 0.0022 \times 10^{5}$ years at the $95 \%$ confidence 1 imit.

Aggarwa $1^{65}$ measured the specific activity of a $99.7 \%$ enriched $233_{\mathrm{y}}$ sample by liquid scintillation counting and alpha proportional counting. Isotope dilution mass spectrometry was used to determine the uraniun concentration of the sample. The result obtained was $1.5885 \pm 0.0085 \times 10^{5}$ years at the $95 \%$ confidence 1 imit.

The weighted average of these four measurements of the ${ }^{233} \mathrm{U}$ half-1 ife is $1.5922 \pm 0.0017 \times 10^{5}$ years at the $95 \%$ confidence level. 
Table $2{ }^{233}$ U Half-1ife

\begin{tabular}{|c|c|c|c|c|}
\hline Author (year) & $\begin{array}{l}\text { Ref- } \\
\text { erence }\end{array}$ & $\begin{array}{l}\text { Total Haif-1ife } \\
\text { Value }\left(10^{5} \text { years }\right)\end{array}$ & Method & Comment \\
\hline Jaffey (1974) & (8) & $1.5910 \pm 0.0030$ & $\begin{array}{l}\alpha \text { proportional } \\
\text { counting }\end{array}$ & $\begin{array}{l}\text { Interme- } \\
\text { diate } \\
\text { geometry }\end{array}$ \\
\hline $\begin{array}{l}\text { Vaninbroukx } \\
(1976)\end{array}$ & (9) & $1.5925 \pm 0.0027$ & $\begin{array}{l}\text { Liquid scintillaton } \\
+4 \pi \alpha \text { proportional } \\
\text { counting }\end{array}$ & $\begin{array}{l}\text { Low } \\
\text { geometry }\end{array}$ \\
\hline $\begin{array}{l}\text { Geidel 'man } \\
\text { (1979) }\end{array}$ & (10) & $1.5937 \pm 0.0033$ & $4 \pi \alpha-x$ coincidence & * \\
\hline $\begin{array}{l}\text { Aggarwal } \\
(1980)\end{array}$ & $(65)$ & $1.5885 \pm 0.0085$ & $\begin{array}{l}\text { Liquid scintillation } \\
+4 \pi \alpha \text { proportional } \\
\text { counting }\end{array}$ & \\
\hline Holden (1980) & & $1.592 \pm 0.002$ & Weighted average & $\begin{array}{l}\text { Recom- } \\
\text { mended } \\
\text { Value }\end{array}$ \\
\hline
\end{tabular}

*Geidel'man's value has the error increased by $50 \%$ because some details are missing e.g. the measured specific activity, the mass of ${ }^{233} \mathrm{U}$ assumed, the mass spectrometric analysis, etc.

$$
\text { IV } 234_{\mathrm{J}}
$$

Most of the early measurements on the ${ }^{234} \mathrm{U}$ half-life were based on the assumption of secular equilibrium between the ${ }^{234} \mathrm{U}$ and ${ }^{238} \mathrm{U}$ specific activity in a natural sample of uranium. As noted in Appendices $I$ and II, the variation of ${ }^{234} \mathrm{U}$ in natural uranium ore concentrates invalidates the assumption of secular equilibrium. Smith and Jackson 11 found an $8 \%$ variation in the ${ }^{234} \mathrm{U}$ content of natural uranium ore concentrates fron sixteen world sources, while Shields ${ }^{12}$ noted ${ }^{234} \mathrm{U}$ abundance variations from a $59 \%$ deficiency to a $72 \%$ excess in uranium found in sandstone deposits in the United States.

One could, in fact, use best estimates of the uranium half-1ives, and a measured specific activity of a uranium srmple to derive an approximate 
estimate of the weight percent of ${ }^{234} \mathrm{U}$ in the sample. Since there was no associated infcrmation on the ${ }^{234} \mathrm{U}$ content in the natural samples of these early measurements, they have been uniformiy ignored in this evaluation.

Fleming ${ }^{13}$ determined the specific activity of a ${ }^{234} \mathrm{v}$ sample enriched to $95.99 \%$. No pulse height analysis was performed since the $235_{\mathbb{U}}$ and $238_{\mathbb{U}}$ activity would be negligible. Alpha counting in mediun geometry was used to determine the specific activity to be $1.370 \pm 0.009 \times 10^{7} \mathrm{dpm} / \mathrm{mg}^{234} \mathrm{U}$. At the $95 \%$ confidence limit, the half-1ife becomes $2.475 \pm 0.032 \times 10^{5}$ years. White ${ }^{14}$ measured the specific activity of two enriched ${ }^{235} \mathrm{U}$ samples that had significant amounts of ${ }^{234} \mathrm{U}$. One sample containing $1.19 \%{ }^{234}{ }_{U}$ was destructively assayed to determine the isotopic composition and provided a half-life of $2.458 \pm 0.031 \times 10^{5}$ years. The second sample, enriched to $0.116 \%$ ${ }^{234} \mathrm{U}$, used back-to-back fission counting to determine the isotopic composition and was not destructively tested. A half-1ife of $2.616 \pm 0.042 \times 10^{5}$ years was obtained. From an analysis of the alpha spectrum, White obtained a specific activity of $1.371 \pm 0.02 \times 10^{7} \mathrm{dpm} / \mathrm{mg}{ }^{234} \mathrm{U}$ (corresponding to a halfIife of $2.47 \pm 0.03 \times 10^{5}$ years for ${ }^{234} \mathrm{U}$ ).

Meadows ${ }^{15}$ measured the half-life of ${ }^{234} \mathrm{U}$ using alpha counting in low geometry, $2 \pi$ proportional counting and chemical analysis on samples containing $0.856 \%, 0.662 \%$, and $1.093 \%{ }^{234} \mathrm{U}$. For the low geometry measurements, the half1 ife was $2.439 \pm 0.048 \times 10^{5}$ years $(95 \%$ confidence limit). No details were given.

DeBievre ${ }^{16}$ used a variety of methods on 83 sources, which were enriched from $0.17 \%$ to $99.87 \%$ in ${ }^{234} \mathrm{U}$ to determine the half-1ife. The resulting value was $2.446 \pm 0.007 \times 10^{5}$ years at the $99.7 \%$ confidence limit. Specific details are missing but were provided by Vaninbroukx ${ }^{16}$. The specific activity of $236_{U}$ was underestimated by $2.5 \%$ in the work. $232 \mathrm{U}$ content was determined for the highly enriched samples of ${ }^{234} \mathrm{U}$ by alpha spectrometry but it is not clear that this was the case for the less enriched samples. $232 \mathrm{U}$ present to 0.03 parts per million (ppm) or $3 . \times 10^{-8}$ grams of $232 \mathrm{U}$ per gram of source would cause a source enriched to $1 \%{ }^{234} \mathrm{U}$ content to give a half-life which was $1 \%$ too low. The highly enriched sources appear to have a slightly larger half-life value than the other sources. In addition, mass determinations by controlled potential coulometry appear to underestimate the mass compared to the isotope 
dilution technique especially for highly enriched samples. To account for possible systematic errors of the above nature, the recomended value for this experiment is $2.446 \pm 0.011 \times 10^{5}$ years ( $95 \%$ confidence 1 imit).

Lounsbury 17 used low geometry alpha counting and mass spectrometric isotope dilution analysis co determine the half-1ife of $234 \mathrm{U}$. Six sources of $1 \% 234 \mathrm{U}$ were prepared. Correcting the measured specific activity of the samples for the present best estimated half-lives of ${ }^{235} \mathrm{U}, 236_{\mathbb{U}}$ and $238_{\mathbb{U}}$ gives an increased activity about $20 \%$ larger than Lounsbury used. This renuces the ${ }^{234} \mathrm{U}$ specific activity of the samples by $0.5 \%$. This correction increases the half-life of ${ }^{234} \mathrm{U}$ by $0.5 \%$ to $2.458 \pm 0.012 \times 10^{5}$ years.

The latest half-1ife measurement for ${ }^{234} \mathrm{U}$ is by Geidel'man ${ }^{18}$ who used $4 \pi$ alpha-x coincidence to determine the specific activity and potentiometric titration to determine the uranium content of a sample enriched to $93.437 \%$ in ${ }^{234} \mathrm{U}$. The value reported for the half-life is $2.459 \pm 0.007 \times 10^{5}$ years (at the $95 \%$ confidence 1 imit).

The weighted average in Table 3 is $2.455 \pm 0.006 \times 10^{5}$ years 


\section{Table $3{ }^{234} \mathrm{U}$ Half-life}

\begin{tabular}{|c|c|c|c|c|}
\hline Author (year) & ference & $\begin{array}{l}\text { Total Half-Life } \\
\text { Value }\left(10^{5} \text { years }\right)\end{array}$ & Me thod & Comment \\
\hline Fleming (1952) & 13 & $2.475 \pm .048$ & $\begin{array}{l}\text { a proportional } \\
\text { counting }\end{array}$ & $\begin{array}{l}\text { Medium } \\
\text { geometry }\end{array}$ \\
\hline White (1965) & 14 & $2.47 \pm 0.06$ & $\begin{array}{l}\text { a proportional } \\
\text { count ing }\end{array}$ & \\
\hline Meadows (1970) & 15 & $2.439 \pm .072$ & $\begin{array}{l}\text { G proportional } \\
\text { counting }\end{array}$ & $\begin{array}{l}\text { Low } \\
\text { geonet ry: }\end{array}$ \\
\hline DeBievre (1972) & 16 & $2.446 \pm .011$ & $\begin{array}{l}\text { Variety of } \\
\text { methods }\end{array}$ & $\approx *$ \\
\hline Lounsbury (1972) & 17 & $2.458 \pm 0.012$ & $\begin{array}{l}\alpha \text { proportional } \\
\text { count ing }\end{array}$ & $\begin{array}{l}\text { Low } \\
\text { geometry }\end{array}$ \\
\hline Geidel'man (1980) & 18 & $2.459 \pm .011$ & $4 \alpha-x$ coincidence & $\star$ \\
\hline Holden (1980) & & $2.455 \pm 0.006$ & $\begin{array}{l}\text { Weighted } \\
\text { average }\end{array}$ & Kecommended \\
\hline $\begin{array}{l}x^{2} \text { see text } \\
\text { *Uncertainties inc }\end{array}$ & creased $y$ & by $50 \%$ because of $\mathrm{m}$ & ing details & \\
\hline
\end{tabular}

Nier ${ }^{19}$ measured 21 samples of radiogenic lead and from the ${ }^{207} \mathrm{~Pb} /{ }^{206} \mathrm{~Pb}$ ratio determined that the actinium series was $(4.6 \pm 0.1$ )\% (assumed standard deviation) as active as the uranium series.Using a best estimate for the ${ }^{235} \mathrm{U} /{ }^{238} \mathrm{U}$ atom ratio for natural uranium of 0.00725 (see Appendix II), the half-life of ${ }^{235} \mathrm{U}$ can be calculated to be $7.04 \pm 0.31 \times 10^{8}$ years $695 \%$ conficience $\mathrm{limit}$ ) by using the expression: atom percent ratio $\left({ }^{235} \mathrm{U} /{ }^{238} \mathrm{l}\right) \mathrm{x}$ half-life ratio $\left({ }^{238} \mathrm{U} /{ }^{235} \mathrm{U}\right)=0.046$.

Sayag ${ }^{20}$ measured the relative alpha activity of uranium due to ${ }^{235_{U}}$ by energy analysis in an ion chamber and obtained 0.0408 \pm 0.0015 ( 1 standard deviation + systematic error). Correcting for the loss of alpha particles outside the central peak ( $10 \%$ assumed by Sayag) using hhite's measurement 14 
that $87.4 \%$ of the ${ }^{235} \mathrm{U}$ act ivity is not hidden tnder the peaks for ${ }^{234} \mathrm{U}$ or ${ }^{238_{\mathrm{UJ}}}$ gives a value $0.0467 \pm 0.0017$. Using the abcye expression, the half-1 fe is $6.94 \pm 0.40 \times 10^{8}$ years $(95 \%$ confidence $\operatorname{limic}$ ).

Fleming ${ }^{13}$ measured the specific activity of a $99.94 \%$ enriched source of $235_{U}$ using mediun geometry alphs counting. Linear differential pulse height analysis was used to separate the ${ }^{234} \mathrm{U}$ and ${ }^{235} \mathrm{v}$ activity. The specific activity was found to be $4 / 40 \pm 100 \mathrm{dpm} / \mathrm{mg} 235 \mathrm{U}$ (1 standard deviation) corresponding to a half-1ife of $7.12 \pm 0.31 \times 10^{8}$ years $(95 \%$ conf idence $\operatorname{limit)}$.

Knight ${ }^{21}$ used the same enriched $235_{U}$ sample as Flening, which had a mass spectrometry analys is of ${ }^{235} \mathrm{v}=99.94 \pm .05 \%, 234 \mathrm{U}<0.022 \%$, and the rerainder assuned to be ${ }^{238} \mathrm{U}$ or $0.038 \%$ (all assumed to be in atom percent). Knight used ion chambers in $50 \%$ geometry and pulse height analysis co determine the $235 \mathrm{v}$ alpha contribution. He reported a specific activity for the saple of 7279.4 $\pm 23.2 \mathrm{dpn} / \mathrm{mg}$ uranium (1 standard deviation). Fleming reported that $63.3 \%$ of the alpha activity was due to $235 \mathrm{U}$. Using this value, one obtains a specific activity for Knight's measurement of $4756 \pm 200 \mathrm{dpn} / \mathrm{mg} 235_{\mathrm{U}}$ corresponding to a half-life of $7.10 \pm 0.32 \times 10^{8}$ years for a $95 \%$ confidence limit. int estimate does not include systenatic error.

wurger 22 measured the alpha activity of $235 \mathrm{U}$ in natural uranito. he used Chiorso's value ${ }^{23}$ of $35.6 \%$ for the percentage of alpha particles from $235 \mathrm{U}$ that are not hidden under $234 \mathrm{U}$ or $238_{\mathrm{y}}$ alpha peaks, and obtained a value of $0.04776 \pm 0.00094$ (assumed to be ? standard deviation, for the relative alpha activity of $235_{\mathrm{U}}$. Using white's estinat ${ }^{14}$ of exposed $235_{\mathrm{U}}$ alpina particles of $87.4 \%$ rather than Ghiorso's value, one obtains a $235_{\mathbb{U}}$ relative activity of 0.04678 and $a$ half-life of $6.93 \pm 0.27 \times 10^{8}$ years $(95 \%$ confidence $\operatorname{limit})$.

White ${ }^{14}$ assayed enriched ${ }^{235} \mathrm{v}$ samples by alpha counting and extracted the ${ }^{235} \mathrm{U}$ fraction by energy analysis. White fourd that $87.4 \%$ of the $235 \mathrm{~V}$ activity was not hidden under the ${ }^{234} \mathrm{U}$ or ${ }^{238} \mathrm{v}$ alpha peaks. The measured specifi= activity was $4741 \pm 60 \mathrm{dpm} / \mathrm{mg} 235 \mathrm{~V}$ (assuned to be 1 standard deviation) (corresponding to a half-life of $7.12 \pm 0.189 \times 10^{8}$ years at 95 ; confidence limit).

Banks 24 determined the $235 \mathrm{gi}$ decay constant from the ${ }^{207} \mathrm{pb} / 206 \mathrm{pb}$ ratios of zircon and uranothorite. A value of $7.087-0.073 \times 10^{8}$ years (assured to be 1 standard deviation) was obtained using a $238^{\circ}$ half-1ife of $4.51 \times 10^{9}$ 
years. Correcting to value of $4.468 \div 10^{9}$ years, one obtains a half-1ife of $7.02+0.14 \times 10^{8}$ years it $95 \%$ confidence 1 imit.

Deruytter ${ }^{25}$ determined the ${ }^{235}$ U alpha activity in naturai cranius using energy analysis wich a silicon solid state junction detector. He correcter $h$ is measured ratio of $0.0406 \pm 0.005$ (standard deviation of ten resalis) using Ghiorso's value ${ }^{23}$ of $85.6 \%$ for ${ }^{235} \mathrm{U}$ alpha particles not hidden under $234 \mathrm{~L}$ or ${ }^{238} \mathrm{U}$ alpha reak:. If one uses white's value of $87.4 \%$ instead, one abtains a ratio of 0.0465 . Using $4.468 \times 10^{9}$ years for the 233 half-life, one obtains $6.97 \pm 0.19 \times 10^{8}$ years for the $235 \mathrm{w}$ alf-lif: at $95 \%$ confidence. Jaffey 26 measured the specific activity of a sample enriched to $99.99886 \%$ in ${ }^{235} \mathrm{U}$ uring iatermediate reonetry alpha countirg. Jaffe; obtained a volue of $4798.1 \pm 3.3 \mathrm{dpm} / \mathrm{mg} 235 \mathrm{u}$ at the $95 \%$ conficence 1 imit for the II $r$ un made, the half-! ife is $7.0373 \pm 0.0106 \times 10^{8}$ years.

Deruyte ${ }^{27}$ measured the ocanching $r$ tio of the central peak of alpha particles to the cotal alpha particies emitteo by 235 using a sample enriched to $99.999 \% 235_{U}$ and used this ratio to recalculate the $235_{U}$ half-life. Jaffey 28 has pointed out that Deruyter's measurement did not show as good a resolutior. in the pulse height analysis as the work of White:4, so Deruytter's earlier measurument ${ }^{25}$ was used with wite's branching rati - bove.

The weighted average from Table 4 for the $235_{\mathrm{U}}$ half-life is $7.037 \pm 0.011 \times 10^{8}$ years. 
Table $4235_{U}$ Malf-Life

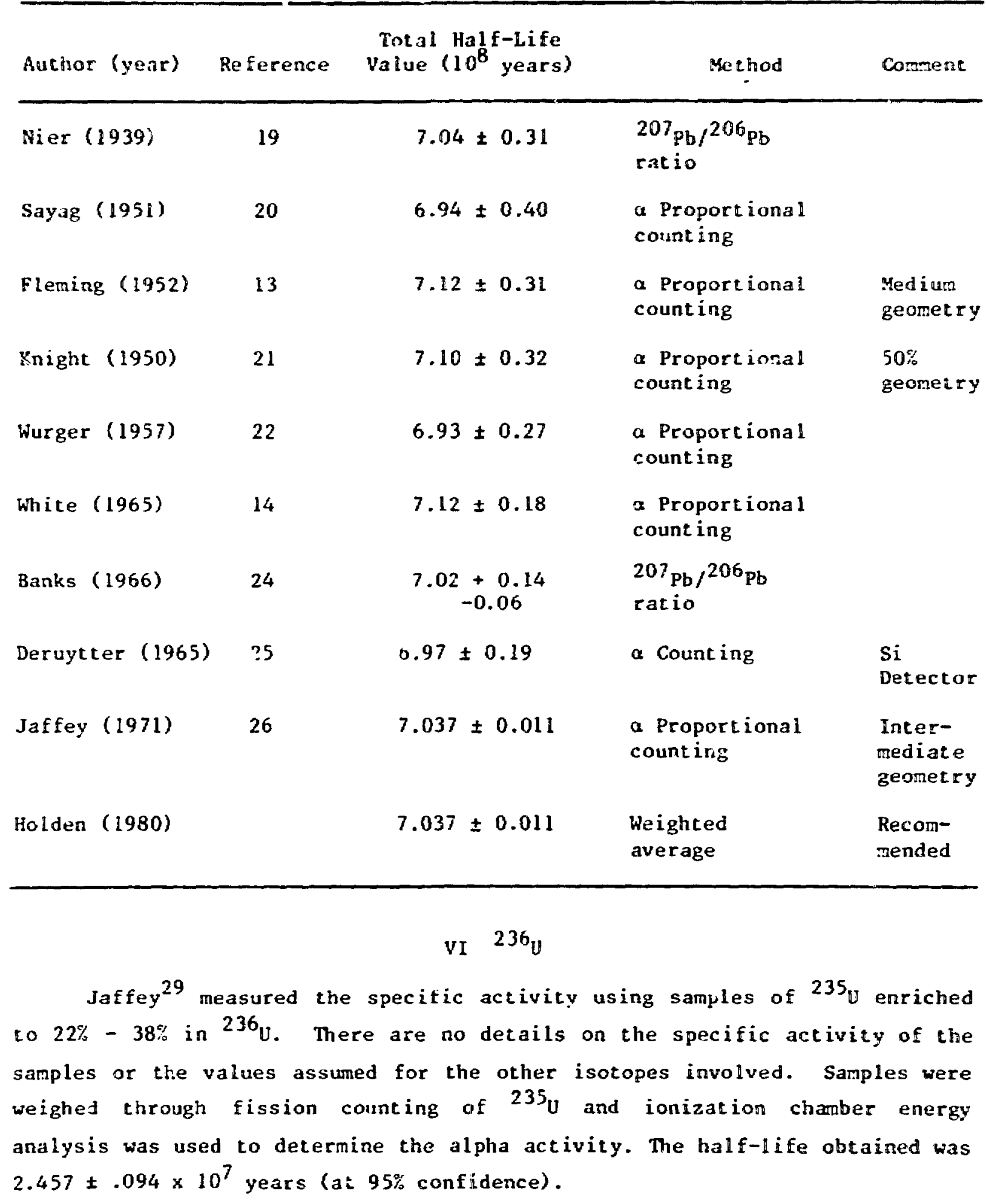


Fleming ${ }^{13}$ neasured the specific activity of $236 \mathrm{y}$ using sources enriched to $96.65 \%$. The alpha activity and the mass spectrometric analysis disagree with the known specific activities of ${ }^{234} \mathrm{U}$ and ${ }^{236} \mathrm{U}$ by more than a factor of two. Details on the actual specific activity of the sample are missing. The resulting half-1ife obtained was $2.391 \pm 0.038 \times 10^{7}$ years (ai $95 \%$ confidence).

Flynn ${ }^{30}$ measured the specific activity of a $99.644 \%$ enriched $236_{U}$ sample. From pulse-height analysis, the ${ }^{236} \mathrm{U}$ contributed $98.314 \%$ of the measured alpha activity. Data from the isotopic analysis did not agree with the pulse height data. Jaffey ${ }^{31}$ has indicated chat there were two wass spectrometric analyses performed on the sanple, one at argonne and the other at Oak Ridge. There was a $40 \%$ difference in the amount of $233 \mathbb{U}$ present in the two analyses and the Oak Ridge values (unpublished) did agree with the pulse height analysis. Using the Oak Ridge value of $99.68 \%{ }^{236} \mathrm{U}$ in the sample, the measured specific activity becomes $143552 \pm 84 \mathrm{dpm} / \mathrm{mg} 236_{\mathrm{U}}$. For the 11 runs, the half-life is $2.3422 \pm 0.0031 \times 10^{7}$ years (at $95 \%$ confidence). The recommended value from Table 5 is $2.342 \pm 0.003 \times 10^{7}$ years for the $236_{U}$ halflife.

\begin{tabular}{|c|c|c|c|c|}
\hline \multicolumn{5}{|c|}{ Table $5236_{\mathrm{U}}$ Half-I.ife } \\
\hline Author (year) & Re ference & $\begin{array}{l}\text { Total Half-Life } \\
\text { value }\left(10^{7} \text { years }\right)\end{array}$ & Method & Comment \\
\hline Jaffey (1951) & 29 & $2.46 \pm 0.14$ & $\begin{array}{l}\text { a Proportional } \\
\text { count ing }\end{array}$ & * \\
\hline Fleming (1952) & 13 & $2.391 \pm 0.057$ & $\begin{array}{l}\alpha \text { Proportional } \\
\text { count ing }\end{array}$ & $*$ \\
\hline Flynn (1972) & 30 & $2.3422 \pm 0.0031$ & $\begin{array}{l}\alpha \text { Proportional } \\
\text { count ing }\end{array}$ & $\begin{array}{l}\text { Ixter- } \\
\text { mediate } \\
\text { geometry }\end{array}$ \\
\hline Holden (1980) & & $2.342 \pm 0.003$ & Weighted average & $\begin{array}{l}\text { Recom- } \\
\text { mended }\end{array}$ \\
\hline
\end{tabular}

*Uncertainties increased by $50 \%$ because of missing details. 


\section{238 u-Total Half-Life}

Except for steyn ${ }^{34}$, all determinations of the specific activity of ${ }^{238_{U}}$ using natural uranium and assuming secular equilibriun have been discarded (see Appendix I). Kienberger ${ }^{32}$ measured both natural uraniun and highly depleced uraniun which had $0.05 \mathrm{ppm}$ of ${ }^{234} \mathrm{U}$. The natural uraniun results which depended upon secular equlibrium and should carry a large systematic error (see Appendix I), have been ignored. Details are sketchy and the systematic errors such as accurate corrections for backscattering and sample self absorption are difficult to estimate. The quoted specfic activity was $742.7 \pm 1.6 \mathrm{dpm} / \mathrm{mg} 238 \mathrm{v}$ corresponding to a half-1ife of $4.489 \pm 0.010 \times 10^{9}$ years.

Leachman ${ }^{33}$ performed $2 \pi$ alpha counting on dipleted uranim samples deposited on platinum. The experiment was described in a footnote to an article on neutron cross sections. No details were given except that the $238_{\mathbb{U}}$ mass was determined by weight and calorimetric analysis. The half-life quoted was $4.56 \pm 0.03 \times 10^{9}$ years. Steyn 34 determined the specific activity of natural uranium using liquid scintillation alpha counting. The measured specific activity is $1520 \pm 2 \mathrm{dpm} / \mathrm{mg}{ }^{238} \mathrm{U}$ corresponding to a half-life of 4.45 $\pm 0.02 \times 10^{9}$ years. However, the assumption of secular equiiibriun carries with it a large systematic error.

Jaffey ${ }^{26}$ measured the specific activity of depleted uranium samples corresponding to 99.9790 atom percent $238_{\mathrm{U}}$ and 99.9997 atom percent $238_{\mathrm{U}}$ using intermediate geometry alpha counting, Jaffey obtained a specific activity of $746.19 \pm 0.41 \mathrm{dpm} / \mathrm{mg}{ }^{238} \mathrm{u}$ (1 standard deviation). This cortesponds to a halflife of $4.468 \pm 0.005 \times 10^{9}$ years (at $95 \%$ confidence).

The recommended value is $4.468 \pm 0.005 \times 10^{9}$ years, where earlier measurements were discarded because of lack of details prevented an adequate estimate of the systematic error or the known systematic ecror meant the measurement was not significant.

\section{VIII. ${ }^{238} \mathrm{U}$ Spontaneous Fission Half-Life}

There is a wide variation in the measured values of the half-life for spontaneous fission of $238 \mathrm{y}$, although the measurements in the past twenty 
years cluster about two values which differ by $20-25 \%$.

The values and the standard deviation for the mica-uraniug sandwich or Lexan-uranium sandwich, i.e. fission track technique in 2 th geometry, have given a disintegration constant of $7.1 \pm 0.1 \times 10^{-17}$ years ${ }^{-1}$ (see Fleischer ${ }^{35}$, Roberts ${ }^{36}$, Kleeman ${ }^{37}$, Leme $^{38}$, Khan ${ }^{39}$, Ivanov 40 and Emma ${ }^{41}$ ). Other techniques lead to larger values for the disintegration constant. Fission track detection in dated uranium glass (Storzer ${ }^{42}$, Wagner $^{43}$ and Thie1 ${ }^{44}$ ) give a weighted average of $8.59 \pm 0.31 \times 10^{-17}$ years $^{-1}$. Radiochemical determination of the fission products of ${ }^{238} \mathrm{U}$ by $\operatorname{Von}$ Gunten $^{45}$ give a value of $8.66 \div 0.22 \times 10^{-17}$ years ${ }^{-1}$. The rotating bubble chamber experiments, where centrifugal forces produce negative pressures in a liquid and energy deposition from spontaneous fission can be detected as in a normal bubble chamber, give a weighted average of $8.447 \pm 0.057 \times 10^{-17}$ years $^{-1}$ (Spadavecchia 46 and Galliker ${ }^{47}$ ). Ionization chamber measurements by Whitehead 48 and Segre 49 give a weighted average of $8.548 \pm 0.253 \times 10^{-17}$ years $^{-1}$. The decay constant from third order correlations in a modified Rossi alpha experiment is $8.66 \pm 0.43 \times 10^{-17}$ years ${ }^{-1}$ (Thury ${ }^{50}$ ).

It should be noted that Fleischer and Price 51 found that the ages of Tektites and other natural glasses obtained by the fission track method coild be made to agree with ages determined by the $\mathrm{K}$-Ar method where a disintegration constant of $6.9 \times 10^{-17}$ years ${ }^{-1}$ was used. Storzer and Wagner 52 pointed out the problems of partial fission track fading in geologic materials and detected this in the case of glasses by measuring track lengths or diameters. When a corrections is made for the annealing influence in tektites, the best agreement with $\mathrm{K}-\mathrm{Ar}$ age determinations results from use of $a^{238} \mathrm{U}$ disintegration constant for spontaneous fission of $8.4 \times 10^{-17}$ years $^{-1}$ from Gentner 53 , Storzer and Wagner 54 , and storzer 55 .

Since storzer 52 pointed out this potential systematic error of fission track fading which when corrected increased the decay constant frcm $6.9 \times 10^{-17}$ to $8.4 \times 10^{-17}$ and the five techniques other than the fission track sandwich give results about $8.5 \times 10^{-17}$ years ${ }^{-1}$, elimination of the fission track sandwich resulcs in the overall average is recommended. The weighted average of the remaining methods excluding the rotating bubble chamber is $8.61 \pm 0.14 \times 10^{-17}$ years. A siraight average of all 5 remaining methods is $8.58 \pm 0.14 \times 10^{-17}$ years, where the error bas been assessed from the other methods since there is no systematic error assessment on the 
rotating bubble chanber. The resulting half-life at $95 \%$ confidence is $8.08 \pm 0.26 \times 10^{15}$ years.

Table 6

${ }^{238} \mathrm{U}$ Spontaneous Fission Decay Constant, $\lambda_{f}{ }^{238}$, and standard deviation.

Author (year) Reference $\begin{gathered}\text { Spontaneous Fission } \\ \text { Decay Consiant } \\ \left(10^{-17} \text { years }\right.\end{gathered} \quad$ Method

\begin{tabular}{|c|c|c|c|}
\hline Whitehouse (1950) & 48 & $8.38 \pm 0.52$ & Ionization chamber \\
\hline Segre (1952) & 49 & $8.60 \pm 0.29$ & Ionization chamber \\
\hline Fleischer (1964) & 35 & $6.85 \pm 0.20$ & $\begin{array}{l}\text { Weighted mean of } 40_{\mathrm{K}} \\
87 \mathrm{Rb} \text { ages of } \\
\text { minerals + mica- } \\
\text { uranium sandwich }\end{array}$ \\
\hline Roberts (1968) & 36 & $7.03 \pm 0.11$ & Nica-uranium sandwich \\
\hline Spadavecchia (1967) & 46 & $8.42 \pm 0.10$ & Ro:at ing bubbi $:$ chamber \\
\hline Von Gunten (1969) & 45 & $8.66 \pm 0.22$ & $\begin{array}{l}\text { Fissign products } \\
\text { from } \\
\text { fro }\end{array}$ \\
\hline Galliker (1970) & 47 & $8.46 \pm 0.06$ & Rotating bubble chamber \\
\hline Storzer $(1970)$ & 42 & $8.49 \pm 0.76$ & $\begin{array}{l}\text { Fission tracks in } \\
\text { dated uranium glass }\end{array}$ \\
\hline Kleeman (1971) & 37 & $6.8 \pm 0.6$ & Lexan-uraniun sandwich \\
\hline Thury (1971) & $5 C$ & $8.66 \pm 0.43$ & Third-order coincidence \\
\hline Leme (1971) & 38 & $7.30 \pm 0.16$ & Mica-uranium sandwich \\
\hline Khan (1973) & 39 & $6.82 \pm 0.55$ & Mica-uranium sandwich \\
\hline Ivanov (1975) & 40 & $7.12 \pm 0.32$ & Mica-uraniun sandwich \\
\hline Emma (1975) & 41 & $7.2 \pm 0.2$ & Mica-uranium sandwich \\
\hline Wagner (1975) & 43 & $8.7 \pm 0.6$ & $\begin{array}{l}\text { Fission tracks in } \\
\text { dated uranium glass }\end{array}$ \\
\hline Thiel (1976) & 44 & $8.57 \pm 0.42$ & $\begin{array}{l}\text { Fission tracks in } \\
\text { dated uranium glass }\end{array}$ \\
\hline
\end{tabular}


Table 7 sumarizes the recommended values for the specific activity and the half-life data for the various uranium isotopes.

Table 7

Recommended Half-life a.d Specific Activity Values

\begin{tabular}{lll}
\hline \multicolumn{1}{c}{ Isotope } & Half-1ife (years) & $\begin{array}{c}\text { Specific Activity or } \\
\text { Decay Constant }\end{array}$ \\
\hline $232_{\mathrm{U}}$ & $69.8 \pm 1.0$ & $4.90 \pm 0.07 \times 10^{10 \mathrm{dpm} / \mathrm{mg} 232_{\mathrm{U}}}$ \\
$233_{\mathrm{U}}$ & $1.592 \pm 0.002 \times 10^{5}$ & $2.139 \pm 0.003 \times 10^{7} \mathrm{dpm} / \mathrm{mg}^{233_{\mathrm{U}}}$ \\
$234_{\mathrm{U}}$ & $2.455 \pm 0.006 \times 10^{5}$ & $1.381 \pm 0.003 \times 10^{7} \mathrm{dpm} / \mathrm{mg}^{234_{\mathrm{U}}}$ \\
$235_{\mathrm{U}}$ & $7.037 \pm 0.011 \times 10^{8}$ & $4.7983 \pm 0.008 \times 10^{3} \mathrm{dpm} / \mathrm{mg}^{235} \mathrm{U}$ \\
$236_{\mathrm{U}}$ & $2.342 \pm 0.0034 \times 10^{7}$ & $1.436 \pm 0.002 \times 10^{5} \mathrm{dpm} / \mathrm{mg}^{236_{\mathrm{U}}}$ \\
$238_{\mathrm{U}}$ (total) & $4.468 \pm 0.005 \times 10^{9}$ & $746.2 \pm 0.8 \mathrm{dpm} / \mathrm{mg}^{238 \mathrm{U}}$ \\
$238_{\mathrm{U}}$ (spon. fiss.) & $8.08 \pm 0.26 \times 10^{15}$ & $8.58 \pm 0.28 \times 10^{-17} \mathrm{years}$ \\
\hline
\end{tabular}

Authors's Note:

As this report goes to press, Vaninbroukx (private communication June 1981) has reevaluated the ${ }^{234} \mathrm{U}$ measurement from Geel (DeBievre ${ }^{16}$ ). Taking into account the items mentioned in this report on that experiment Vaninbroukx recommends $t_{1 / 2}=2.450 \pm 0.008 \times 10^{5}$ years. My recommended weighted average becomes $t_{1 / 2}\left({ }^{234} U\right)=2.454 \pm 0.006 \times 10^{5}$ years. 
Acknowl edgements

Helpful discussions and/or other assistance was provided by $I$. L. Barnes (NBS), M. R. Bhat (BNL), T. W. Burrows (BNL), A. H. Jaffey (ANL), W. Poenitz (ANL), J. R. Stehn (BNL), and R. Vaninbroukx (CBMN-Geel). 
A number of determinations of the half-1ife of ${ }^{234} \mathrm{U}$ and $238_{\mathbb{U}}$ are based on measurements of the specific activity of natural uraniue samples and the assumption of secular equilibrium in those samples. In a radioactive decay chain, when a daughter nuclide has a much smaller half-life than its parent nuclide, at a time interval very long compared to the daughter's lifetime, the growth and decay of the daughter 1 s controlled by the parent and the two nuclides are in secular equilibrium i.e. their activities, $N \lambda$, are equal, where $N$ is the number of atoms and $\lambda$ is the decay constant $(\lambda=$ natural logarithm 2/half-life). Since the half-1ife of ${ }^{234} \mathrm{U}$ is only $10^{5}$ years and the age of the earth is orders of magnitude greater, $10^{9}$ years, all of the ${ }^{234} \mathrm{U}$ orlginally formed in natural uranium has long since decayed. The ${ }^{234} \mathrm{U}$ now present in uranium is due to the ${ }^{238_{\mathrm{U}}} \mathrm{U}$ decay series, i.e., ${ }^{238_{\mathrm{U}}} \mathrm{d}$ decay $234^{\mathrm{Th}}$ $B$ - decay ${ }^{234} \mathrm{~Pa} B-$ decay $234 \mathrm{U}$. In a closed system, the ${ }^{238} \mathrm{U}$ and the ${ }^{234} \mathrm{U}$ should be in secular equilibrium. This implies that a measurement of the specific activity of a natural uranium sample when corrected for the small amount of ${ }^{235} \mathrm{U}$ activity $(\approx 2.2 \%)$ would provide a determination of the equal amounts of activity of the ${ }^{238} \mathrm{U}$ and ${ }^{234} \mathrm{U}$ present. Given the isotopic composition of ${ }^{238} \mathrm{U}$ and ${ }^{234} \mathrm{U}$ in the natural sample, one could calculate the specific activity and half-life of each nuclide. This procedure has been followed in a number of measurements. However if a closed system is not maintained, the secular equilibrium assumption is not valid. Given the specific activity or half-life for ${ }^{234} \mathrm{U}$ and ${ }^{238} \mathrm{U}$, one can derive the "theoretical" isotopic abundance of $234 \mathrm{~J}$ implied by secuiar equilibrium. From the values in Table 7 , the ${ }^{234} \mathrm{U}$ abundance is $54.55 \pm 0.15 \times 10^{-4}$ atom percent (at $95 \%$ confidence) or $54.55 \pm 0.15$ parts per million ( $p$ pol in natural uranium assuming secular equilibrium. The "theoretical" specific activity of natural uranium is calculated from the above abundance to be $1515.7 \pm 2.7 \mathrm{dpm} / \mathrm{mg}$.

As shown in Appendix II, Smith ${ }^{11}$ has determined a ${ }^{234} \mathrm{U}$ variation from $50.9 \mathrm{ppm}$ to $54.8 \mathrm{ppm}$ in various world-wide sources of uranium ore. Rosholt ${ }^{56}$, 57 , 58 has found extreme values for ${ }^{234} \mathrm{U}$ of $22.2 \mathrm{ppm}$ to $92.5 \mathrm{ppm}$ in sandstone deposits of natural uranium in the United States. The calculated specific activities are show in Table 8 . With such a large variation $(\approx 2)$ in the specific activity of natural uranium, no value can be quoted without knowledge of the isotopic composition of the sample. 
Table 8 Specific Activity of Natural Uranium

\begin{tabular}{llc}
\hline \multicolumn{1}{c}{ Source } & Reference & Specific Activity (dpm/mg) \\
\hline Secular Equilibrium & This Ieport & $1515.7 \pm 2.7$ \\
Smith & 11 & 1465 to 1519 \\
Rosholt & $56,57,58$ & 1077 to 2031 \\
\hline
\end{tabular}


Appendix II Natural Variation of the Uranium Isotopic Composition

This discussion should be considered as an update of reference 1 for uranium. Smith ${ }^{11}$ has measured the variation of ${ }^{234} \mathrm{U}$ on 16 vorld sources, while Cowan $^{59}$ has measured the variation in $235_{U}$ for some 90 samples, which included the sixteen sources of Smith. Tables 9 and 10 summarize these two sets of results for U.S. and non U.S. ore sources respectively.

Although the ${ }^{234} \mathrm{U}$ abundance value varies significantly in Tables 9 and 10 , it can be seerl that the ratio ${ }^{238} \mathrm{U} /{ }^{235} \mathrm{U}$ is fairly constant at $137.9 \pm$ 0.06 .

Rosholt $56,57,58$ in series of papers reviewed the fractionation of uranium in various sandstone deposits in the United States. Rosholt 58 found samples with a ${ }^{234} \mathrm{U}$ abundance as $10 \mathrm{w}$ as $22.2 \mathrm{ppm}$ in Powder River basin Wyoming. In Shirley Basin, Wyoming sandstone, Rosholt 56 found samples with a ${ }^{234} \mathrm{U}$ abundance as high as 92.1 ppm. Finally, in Gas Hill, Fremont county, Wyoming, Rosholt 57 found samples enriched in ${ }^{234} \mathrm{U}$ to $92.5 \mathrm{ppm}$ less than a half foot from a sample with a ${ }^{234} \mathrm{U}$ abundance of $45.7 \mathrm{ppm}$. The extreme ranges for the ${ }^{238} \mathrm{U} /{ }^{235_{\mathrm{U}}}$ ratio found by Rosholt were 137.3 to 138.7 . 
Table 9 Uranium Isotopic Composition (U.S. samples)

\begin{tabular}{|c|c|c|c|c|}
\hline Source & $\begin{array}{l}\text { atom \% } \\
234 \\
\text { (p pm) }\end{array}$ & $\begin{array}{l}\text { atom \% } \\
235 \\
\text { (p pm) }\end{array}$ & $\begin{array}{l}\text { atom \% } \\
238 \\
(\%)\end{array}$ & $\begin{array}{l}\text { Half-life } \\
23 l t U \text { ( } 10^{5} \text { years) } \\
\text { assuming secular } \\
\text { equilibrium }\end{array}$ \\
\hline Ford, Washington & 54.1 & 7198 & 99.275 & 2.435 \\
\hline Lakeview, Oregon & $52.2-52.6$ & $7200-7202$ & 99.275 & $2.349-2.367$ \\
\hline $\begin{array}{l}\text { Fremont County } \\
\text { Wyoming }\end{array}$ & $51.9-52.8$ & 7197 & 99.275 & $2.336-2.376$ \\
\hline $\begin{array}{l}\text { Edgemont, } \\
\text { South Dakota }\end{array}$ & 50.9 & 7196 & 99.275 & 2.291 \\
\hline Moab, Utah & $53.0-53.8$ & 7197 & 99.275 & $2.385-2.421$ \\
\hline $\begin{array}{l}\text { Kermac, } \\
\text { Ambrosia Lake } \\
\text { New Mexico }\end{array}$ & $53.6-54.3$ & 7196 & 99.275 & $2.412-2.444$ \\
\hline $\begin{array}{l}\text { Cl imax Mountain } \\
\text { Colorado }\end{array}$ & 54.3 & 7196 & 99.275 & 2.444 \\
\hline $\begin{array}{l}\text { Homestake, } \\
\text { Ambrosia Lake } \\
\text { New Mexico }\end{array}$ & 54.7 & 7196 & 99.275 & 2.462 \\
\hline
\end{tabular}


Table 10 Uranium Isotopic Composition (non U.S.A. Samples)

\begin{tabular}{|c|c|c|c|c|}
\hline Source & $\begin{array}{l}\text { atom } z \\
234 \\
\text { (Pp: }\end{array}$ & $\begin{array}{l}\text { atom } x \\
235 \\
\text { (ppon) }\end{array}$ & $\begin{array}{l}\text { atom } x \\
238 \\
(x)\end{array}$ & $\begin{array}{l}\text { Half-11fe } 234 \mathrm{U} \\
\text { (10 years) } \\
\text { (assuning secular } \\
\text { equilibrium }\end{array}$ \\
\hline Belgian Congo & 54.8 & 7200 & 99.275 & 2.466 \\
\hline $\begin{array}{l}\text { Radium Hill, } \\
\text { Australia }\end{array}$ & 53.3 & 7198 & 99.275 & 2.399 \\
\hline $\begin{array}{l}\text { Blind River, } \\
\text { Ontario } \\
\text { (Canada) }\end{array}$ & 53.3 & 7199 & 99.275 & 2.399 \\
\hline $\begin{array}{l}\text { Marion River } \\
\text { Northwest Terr. } \\
\text { (Canada) }\end{array}$ & 53.9 & 7198. & 99.275 & 2.426 \\
\hline $\begin{array}{l}\text { Rum Jungle, } \\
\text { Australia }\end{array}$ & 54.3 & 7198 & 99.275 & 2.444 \\
\hline South Africa & $53.3-54.0$ & 7199. & 99.275 & 2.415 \\
\hline $\begin{array}{l}\text { Lake Athabaska, } \\
\text { Saskatchewan } \\
\text { (Canada) }\end{array}$ & 53.9 & 7199 & 99.275 & 2.426 \\
\hline $\begin{array}{l}\text { Bancroft } \\
\text { Ontario, Canada }\end{array}$ & 54.4 & 7198. & 99.275 & 2.448 \\
\hline
\end{tabular}

For the ninety world-wide samples of Cowan 59 , the $235_{\mathrm{J} /} 238_{\mathrm{U}}$ ratio has twin peaks at .0072495 and .0072515 , with extreme values of .007241 to .007256 , while the four U.S. locations that Rosholt surveyed gave an average value for the ratio of .007242 with extreme values of 0.00721 to 0.00728 . A best estimate for the ratio is 0.00725 .

In addition to the above studies of the variation in isotope atom ratios in samples, ${ }^{234} \mathrm{U} /{ }^{238} \mathrm{U}$ disequilibrium studies have continued since the 1955 Therdyntsev report ${ }^{60}$ of large deviations in the activity ratio of ${ }^{234} \mathrm{U}$ to $^{238} \mathrm{U}$ occur in nature. The ${ }^{234} \mathrm{U}$ is used to $\mathrm{d}=\mathrm{s}=\mathrm{geological}$ events. Since the activity ratio should be unity for secular equilibrium, a non-unit value 
implies the variations of $234 \mathrm{v}$ abundance in the uranium sappie. sinee

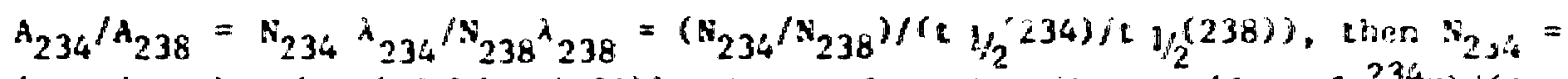

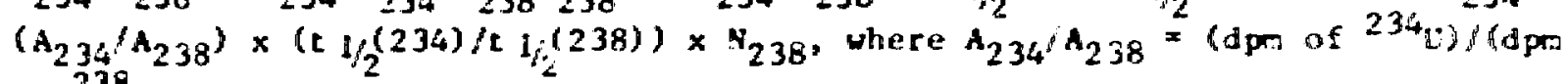
c 238 (i)

Osmond ${ }^{3}$ has reviewed the data and for uraniug dissolved in grourdwater reports extremes corresponding to $234 \mathrm{C}$ abundances of 27.4 ppo to 383.5 pro in well water from Florida and Texas, respectively.

Similarly, Rosholt 61 studied volcanic tuff in California and tean and detemined activity ratios corresponding to 23 , aburdances of 90.0 ppo ard $27.8 \mathrm{ppn}$, respectively.

For carbonates in ocean water, $T$ rber ${ }^{62}$ found average activi:y ratios corresponding o a $234 \mathrm{v}$ abundance of $62.7 \mathrm{ppr}$.

The mechanis involved to accoun: for biese enhancements and discrepancies are alpha recoil leaching and alpha recoil adsurption sirce tive $234_{0}$ is the daugher product of the $238_{4}$ alpha decay. Rostools has forrat samples depleted and enhanced in $234 \mathrm{~W}$ within $/ / 2$ foot ot each other. $234_{\mathrm{ng}}$ is relocated by recoil and radiation danage into crystal defects witere it is core readily accessible to oxidation.

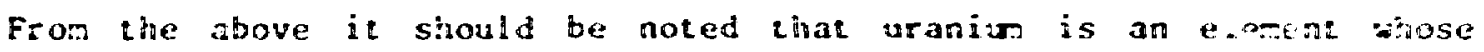
isotopic composition is variable in naturs and if the 234 abundanse is a cricical quantity, it should be directy detemined for lie particular srole of interest. 
Appendix III Parameters of the Evaluation

In the computation of speciflc activity in dpa/ag and half-ilfe in years, the following values were used for the 1 isted parameters:

Paraneter

At onic Weight of uranium

Atomf Mass of $232 \mathrm{~V}$

$234 \mathrm{U}$

$235 \mathrm{U}$

2360

$238 \mathrm{U}$

One year (solar)

Avogadro's number
Value

238.0289

232.03714

233.039629

$234.04094^{7}$

235.043925

236.045563

238.050786

525949 minutes

$6.022045 \times 10^{23} \mathrm{zol}^{-1}$
Source

Ho Iden 2

hapstra 63

"

•

•

•

"

$\operatorname{conen}^{64}$

\section{REFEREACES}

1. X. E. Holden, Isotopir composition of the elements and their variation in nature: a preliminary report, Brookhaven lational Laboratory Report BNL-NCS-50605, March 1977.

2. N. E. Holden et al., Atomic weights of the elements 1979: Report of the IUPAC Commission on Atomic Heights and Isotopic Abundances, Pure ApPl. Chem. 522349 (1980).

3. J. K. Oswond, J. B. Cowart, The Theory and uses of uranium isotopes in hydrology, Atomic Energy Rev. 14 621 (1976).

4. P. A. Sellers, C. M. Stevens, M. H. Studier, The half-1ife of 232 , Phys. Rev. $94952(1954)$.

5. J. M. Chilton et al., A redeterwination of the half-life of uranius-232, J. Inorg. Nuc 1. Chem. 26395 (1964).

6. S. K. Aggarwal et al., Half-1 ife of 232 W, Phys. Rev. C20 1533 (1979).

7. R. W. Durham, Half-life of $233_{U}$ in Progress Report, Chemistry and Materials Division, Atomic Energy of Canada, Ltd, AECL-3527, 35 (1969).

8. A. H. Jaffey et al., New determination of the $233 \mathrm{U}$ specific activity and half-life, Phys. Rev. C9 1991 (1974).

9. R. Vaninbroukx et a1., New determination of the half-1ife of $233 \mathrm{v}$, Phys. kev. Cl $33: 5$ (1976).

10. A. M. Geidel'man et al., Half-1ife of 233 Izv. Akad. Nauk SSSR, Ser. Fiz. 43928 (1979).

11. R. F. Solth, J. M. Jackson, Variations in $234 \mathrm{U}$ concentrations of satural uranium, Paducah Gaseous Diffuston Plant Report, KY-58: (1959).

12. W. R. Shields, priv. comm. March 1971.

13. E. H. Flealng, Jr., A. Ghiorso, B. B. Cunningham, The specific alpia activities and half-1tives of $234 \mathrm{v}, 235 \mathrm{v}$, and $236 \mathrm{U}$, Phys. Rev. 88642 (1952).

14. P. H. White, G. J. Wall, F. R. Pontet, A remeasurement of the haif-1ife of 235U, J. Nucl. Energy A/B19 $33(1965)$. 
15. J. W. Meadows, The alpha half-life of $4-234$ in the Argonne Nacional Laboratory Reactor Physics Division Annual Report July 1, J968-June 30, 1969, ANL-7610, 44 (1970).

16. P. de Bievre e: al., The half-1 ife of ${ }^{234} \mathrm{v}$ Proc. Int. Conf. Chemical Nuc I. Data, Measurements and Applications, Canterbury England Sep:. 2022, 1971. Inst. Civil Engineers, London p. 22I (1972) and $R$. Vaninbroukx, priv, comm. Dec. 22, 1980.

17. M. Lounsbury, R. H. Durham, the alpha half-life of ${ }^{234} \mathrm{U}$, Proc. In:. Conf. Chemicai hucl. Data, Heasurements and Applicatons, Canterbury, England, Sept. 20-2], 1971. Inst. Civil Engineers, London, p. 215 (1972).

18. A. M. Ge idel'man et a1., Half-life of $234 \mathrm{U}$, IzV. Akad. Nauk SSSR, Ser. Fiz. $44927(1980)$.

19. A. O. Nier, The isotopic constitution of uraniun and the half-1ives of the uranium iso:opes, Phys. Rev. 55150 (1939)

20. G. Sayag, Mesure du rapport des activites de $235_{\mathrm{U}}$ e: ${ }^{234} \mathrm{U}$ dans $\mathbb{1}^{\circ}$ uraniun naturel a l'aide d'une chambre d'ionisation a grille, Compt. Rendus. 232 2091 (1951).

21. G. B. Knight, Specific alpha activity of U-235, in Oak Ridge National Laboratory Report K-663 unpublished (Aug. 1950).

22. Bithrger, K. P. Meyer, P. Huber, Lebensdauer und Zerfallsschena von

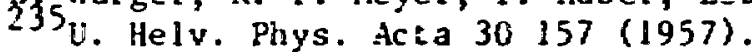

23. A. Chiorso, Complex alpha spectrum of $235_{\mathrm{U}}$ phys Rev. 82979 (1951).

24. P. 0. Banks, L. T. Silver, Evaluation of the decay constant of uraniun235 from lead isotope ratios, J. Geophys. Res. 714037 (1966).

25. A. J. Deruytter, I. G. Schröder, J. A. Moore, Measurement of the halflife of ${ }^{235} \mathrm{v}$ fo: alpha emission, Nucl. Sci. Eng. 21325 (1965).

26. A. H. Jaffey, et al., Precision measurtment of half-lives and specific activities of $235_{\mathrm{U}}$ and $238_{\mathrm{U}}$, Phys. Rev. C4 1889 (1971).

27. A J. Deruytier, G. hegener-Penning, Redetermination of the half-life of $235_{U}$ for alpha emission Phys. Rev. Ci 0383 (1974).

28. A. H. Jaffey, Redetermination of the half-life of ${ }^{235} \mathrm{U}$ For alpnc enission: A reply, Phys. Rev. Clo 386 (1974).

29. A. H. Jaffey, H. Diamond, A. Hirsch, J. Mech., Half-life and alpha particle energy of $236 \mathrm{U}$, Phys. Rev. 84785 (1951).

30. K. F. Flynn, A. H. Jaf fey, W. C. Bentley, A. M. Essling, Precision measurement of half-1 i re and specific activity of $236 \mathrm{U}$, J. Inorg. Nucl. Chen. 341121 (1972).

31. A.. Ja $\overrightarrow{f f}$ ey, priv. comn., Nov. $10,1980$.

32. C. A. Kienberger, The uranium-234 content of natural uranium and the specific alpha activity of the isocopes, Phys. Rev. 761561 (1949).

33. R. B. Leachman, H. W. Schmitt, The cross section for $238 \mathrm{U}$ fission by $f$ ission neutrons, J. Nucl. Energy 438 (1957).

34. J. Steyn, 5. W. E. Strelow, The determination of tine half-life of $238_{\mathrm{v}}$ by absolute counting of alpha particles in a $4 \pi$ liquid scintillation counter, in Metrology of Radionuclides edited by A. Sanielevici, P. 155, International Atomic Energy Agency, Vienna, Austria, 1959.

35. R. L3 Fleischer and P. B. Price, Decay constant for spontaneous fission of 238 U, Phys. Rev. 13.3 2975 (1964).

36. J. H. Robert R. Go: d and R. J. Armani, Spontaneous-fission decay constant of ${ }^{238} \mathrm{l}$, Phys. Rev. 174 1482 (1968).

37. J. D. Kleenan and J. F. Lovering, A determination of the deciy constan: for spontaneous fission of natural uranium using fission track accumulation, Geochim. Cosmochim. Acta 35637 (1971). 
38. M. P. T. Leme, C. Renner and M. Catcani, Determinacion of the decay constant for spontaneous fission of ${ }^{238_{U}} \mathrm{U}$, Nucl. Instrum. Hethods $9 ! 577$ (1971).

39. H. A. Khan and S. A. Murrani, Measurements of spontaneous-fission secay constant of 238 with a mica solid state track detector, Radiation Ef fects 17, 133 (1973).

40. K. N. Ivanov and K. A. Petrzhak, Probability of fission by $1.33 \mathrm{HeV}$ $\gamma$-rays and spontaneous fission haif-life for ${ }^{238} \mathbb{U}$, Sov. Atom. Energy

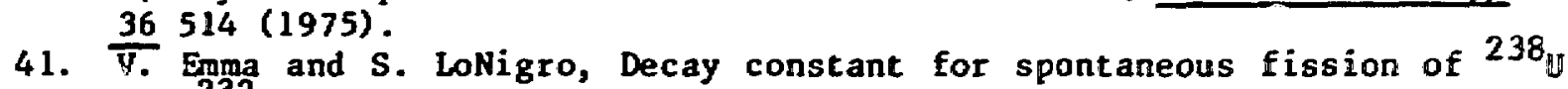
and ${ }^{232} \mathrm{Th}$, Nuc 1. Instrum. Methods 128355 (1975).

42. D. Storzer, Spaltspuren des 238-Vrans and ihre Bedeutung fur die geologische Gesckichte naturlicher Glaser, Thesis, Universitat He idelberg (1970).

43. G. A. Wagner, G. M. Reimer, B. S. Carpenter, H. Faul, R. van der Linden and $R$. Gijbels, The spontaneous fission rate of $U-238$ and fission track dat ing, Geochim. Cosmochim. Acta 391279 (1975).

44. $K$. Thiel and $W$. Herr. The ${ }^{238} \mathrm{v}$ Spontaneous fission decay constant redetermined by fission tracks, Earth Planet, Sci. Lett. 3050 (1976).

45. H. R. von Gunten, Distribution of mass in spontaneous and neutroninduced fission, Actinides Rev. 1275 (1969).

45. A. Spadavecchia and B. Hahn, Die Rotationskammer and einige Anwendungen, Helv. Phys. Acta 401063 (1967).

47. D. Galliker, E. Hugentobler and B. Hahn, Spontane Kernspaltung von ${ }^{238_{U}}$ and $241_{\mathrm{Am}}$, Helv. Phys. Acta 43593 (1970).

48. W. J. Whitehouse and W. Galbraith, Energy spectrum of fragments rom the spontaneous fission of natural uranium, Philos. Mag. 41429 (1950).

49. E. Segre, Spontaneous fission, Phys. Rev. 8621 (1952).

50. W. M. Thury, Die Bestimmung der Spontanspaltrate von U-238 mit Hilfe der Messung von Korrelations funktionen dritter Ordnung, Acta Phys. Aus. 33 375 (1971).

51. K. L. Fleischer and P. B. Price, Fission track evidence for the simultaneous origin of tektites and other natural glasses, Geochim. Cosmoch im. Acta 28161 (1964).

52. D. Storzer and G. A. Wagner, Correction of thermally lowered fission track ages of tektites, Earth Planet. Sci. Lett. 5463 (1969).

53. W. Gentner, D. Storzer and G. A. Hagner, Das A.te von Tektiten unö verwandten Glasern, Naturwiss. 56255 (1969).

54. D. Storzer and G. A. Hagner, Fission track ages of North American tektites, Earth Planet. Sci. Lett. 10435 (1971). 